Original investigation

Open Access

\title{
Fenofibrate Intervention and Event Lowering in Diabetes (FIELD) study: baseline characteristics and short-term effects of fenofibrate [ISRCTN6478348I]
}

\author{
The FIELD Study Investigators*
}

\author{
Address: The FIELD Study, C/o NHMRC Clinical Trials Centre, Mallett St Campus, University of Sydney NSW 2006, Australia \\ Email: The FIELD Study Investigators* - FIELDTrial@ctc.usyd.edu.au \\ * Corresponding author
}

Published: 22 August 2005

Received: 29 June 2005

Cardiovascular Diabetology 2005, 4:13 doi:10.1186/1475-2840-4-13

Accepted: 22 August 2005

This article is available from: http://www.cardiab.com/content/4/I//3

(C) 2005 Keech and The FIELD Study Investigators; licensee BioMed Central Ltd.

This is an Open Access article distributed under the terms of the Creative Commons Attribution License (http://creativecommons.org/licenses/by/2.0), which permits unrestricted use, distribution, and reproduction in any medium, provided the original work is properly cited.

\begin{abstract}
Objective: The Fenofibrate Intervention and Event Lowering in Diabetes (FIELD) Study is examining the effects of long-term fibrate therapy on coronary heart disease (CHD) event rates in patients with diabetes mellitus. This article describes the trial's run-in phase and patients' baseline characteristics.

Research design and methods: FIELD is a double-blind, placebo-controlled trial in 63 centres in 3 countries evaluating the effects of fenofibrate versus placebo on CHD morbidity and mortality in 9795 patients with type 2 diabetes mellitus. Patients were to have no indication for lipid-lowering therapy on randomization, but could start these or other drugs at any time after randomization. Follow-up in the study was to be for a median duration of not less than 5 years and until 500 major coronary events (fatal coronary heart disease plus nonfatal myocardial infarction) had occurred.

Results: About 2100 patients (22\%) had some manifestation of cardiovascular disease (CVD) at baseline and thus high risk status. Less than $25 \%$ of patients without CVD had a (UKPDS determined) calculated 5 -year CHD risk of $<5 \%$, but nearly all had a 5 -year stroke risk of $<10 \%$. Despite this, half of the cohort were obese (BMI > 30), most were men, two-thirds were aged over 60 years, and substantial proportions had NCEP ATP III features of the metabolic syndrome independent of their diabetes, including low HDL $(60 \%)$, high blood pressure measurement or treatment for hypertension (84\%), high waist measurement (68\%), and raised triglycerides (52\%).

After a 6-week run-in period before randomisation with all participants receiving $200 \mathrm{mg}$ comicronized fenofibrate, there were declines in total and LDL cholesterol $(10 \%)$ and triglycerides (26\%) and an increase in HDL cholesterol (6.5\%).

Conclusion: The study will show the effect of PPAR-alpha agonist action on CHD and other vascular outcomes in patients with type 2 diabetes including substantial numbers with low to moderate CVD risk but with the various components of the metabolic syndrome. The main results of the study will be reported in late 2005.
\end{abstract}




\section{Introduction}

The cardiovascular benefits of long-term treatment using HMG-CoA reductase inhibitors (statins) have been conclusively shown in several studies (summarized in [1]) of people with and without established cardiovascular disease, which have included more than 18000 men and women with diabetes mellitus [2-8]. To date, however, no clinical trials using peroxisome proliferator-activated receptor (PPAR) alpha agonists (such as fibrates) have specifically examined cardiovascular event rate changes in large numbers of patients with diabetes mellitus. In the 6 trials of fibrates reported to date the aggregate number of patients with diabetes mellitus is just over 2000 [9-14], with VA-HIT accounting for about $40 \%$ of these [11]. Fibrates cause favorable changes to the typical lipid profile of type 2 diabetes mellitus, by raising high-density lipoprotein (HDL) cholesterol, lowering triglycerides, and reversing the tendency to formation of small, dense, lowdensity lipoprotein (LDL) cholesterol particles [15-18].

If PPAR alpha agonists (and other modulators of the PPAR axis) are to assume a role as mainstream agents for reducing the risk of fatal and nonfatal cardiovascular events, adequately powered placebo-controlled trials, similar to the statin trials, are needed. They should include patients with diabetes of both sexes across a wide range of age and absolute cardiovascular risk.

The Fenofibrate Intervention and Event Lowering in Diabetes (FIELD) Study is a 3-country (Australia, New Zealand and Finland), 63-centre, double-blinded placebocontrolled trial evaluating the effects of fenofibrate compared with placebo on coronary heart disease morbidity and mortality in 9795 patients with type 2 diabetes [1]. The study incorporated a 6-week active-treatment run-in period, with all subjects receiving $200 \mathrm{mg}$ comicronized fenofibrate before randomization to long-term placebo or active treatment. This article reports the baseline and treatment-entry characteristics of this cohort and defines the absolute risk of its study population.

\section{Methods}

The design of the FIELD study has been described in detail elsewhere [1]. The study was approved by local ethics committees at each participating institution. In brief, FIELD is a randomized double-blind, placebo-controlled, parallel-group trial. Participants are middle-aged to elderly people (50 to 75 years of age) with type 2 diabetes mellitus considered to be at risk of coronary heart disease. The first patient in FIELD was registered in November 1997 and randomized in February 1998. A total of 14247 subjects were registered, and 13900 were screened in clinics for eligibility at Visit 1.
Patients were recruited from 63 centres in Australia, New Zealand and Finland. Those with and without known vascular disease were eligible for participation provided that, at randomization, the usual physician considered that there was no current indication for lipid-modifying treatment. This meant that some patients meeting the FIELD eligibility criteria for lipid levels were instead treated by their usual doctors once they became aware of the patients' lipid profile at screening; therefore, such patients were not randomized and were not included in the study. Patients with or without lipid abnormalities, such as low HDL cholesterol or elevated triglycerides, were eligible if the total blood cholesterol level at screening fell between 3.0 and $6.5 \mathrm{mmol} / \mathrm{L}$ (about 115-250 mg/dL) and either the total-to-HDL cholesterol ratio was 4.0 or higher, or the triglyceride level was over $1.0 \mathrm{mmol} / \mathrm{L}$. Patients were excluded if they had triglyceride levels over $5.0 \mathrm{mmol} / \mathrm{L}$. Lipid entry criteria were consistent with recruiting people who would not qualify for fully subsidised lipid-modifying treatment under the government guidelines in all 3 countries. Participants could not be taking any lipid-modifying therapy at the start of the dietary run-in period. However, the protocol allows for statin or other lipid-lowering therapy to be added at any time after randomization and recommends continuing study medication. The study is thus evaluating the role of fenofibrate on a background of usual care and will provide safety data on fibrate therapy in combination with other lipid-lowering treatments. A prespecified analysis will explore the effects of fenofibrate separately among those patients taking other lipidlowering agents during follow-up and those taking study treatment alone. Intention-to-treat methods of analysis will result in conservative estimates of any effects of fenofibrate in the event that drop-ins to statin treatment are more frequent in the placebo-treated group. Confounding with respect to other drug use should be prevented by the randomization process, which will result in good balance across the treatment groups.

Patients known to have type 2 diabetes (identified through hospital clinic records, diabetes society membership lists and various patient registers) were invited to attend a special clinic. After clinical screening of patients for eligibility and obtaining informed consent, blood was taken for biochemical measurements of fasting glucose, lipids, apolipoproteins, fibrinogen, HbA1c, insulin, renal and liver biochemistry, and homocysteine, and urine was collected for albumin-to-creatinine ratio. The LDL cholesterol level was calculated from the Friedewald formula [19]. Biochemical analysis used standard methods in 2 central laboratories (Southpath, Flinders Medical Centre, Adelaide, Australia, and the National Public Health Institute, Helsinki, Finland) which were aligned by using reference material from the Canadian External Quality Assurance Laboratory, Vancouver, Canada, traceable back 
to CDC, Atlanta, USA. Both laboratories participated in local external quality assurance programs. Eligibility was confirmed for consenting participants. All screened patients were asked to follow agreed national dietary recommendations for type 2 diabetes mellitus and provided with literature summarizing key dietary recommendations. Patients were asked to return after 4 weeks of dietary adherence for review of their interest in participating in the long-term trial, and for a check of laboratory eligibility (triglyceride $<5.0 \mathrm{mmol} / \mathrm{L}$, serum creatinine $<130 \mu \mathrm{mol} / \mathrm{L}$, alanine aminotransferase (ALT) less than twice the upper limit of normal) and to commence a single-blind placebo run-in phase of one capsule daily with breakfast for a further 6-week period. Upon the patients' return after the placebo period, consenting eligible patients were then entered into a 6-week single-blind active run-in period. During this time, they were to take comicronized fenofibrate $200 \mathrm{mg}$ once daily. The placebo run-period was conducted to familiarize patients with the long-term commitment to the trial. The active run-in was conducted to provide data on the short-term effects of fenofibrate therapy on cholesterol levels for all randomized patients.

After the 16-week run-in procedures had been completed, a further blood sample was taken at the time of randomization (week 0) to determine the short-term effects of the comicronized fenofibrate on total cholesterol, HDL cholesterol, triglycerides, LDL cholesterol and fibrinogen. At this visit, patients were randomized, by a stratified adaptive randomization scheme, to receive either fenofibrate (200 mg comicronized formulation) or matching longterm placebo as one capsule daily with breakfast [1]. The final patient was randomized to the study on 3 November 2000.

All patients were then followed up through regular visits to a special clinic set in place for the purposes of the study in addition to routine care provided through the family doctor and usual diabetes clinics.

For a primary outcome of CHD events (CHD death plus nonfatal MI), it is projected that approximately $500 \mathrm{CHD}$ events will have occurred when a median of 5 years of follow-up has elapsed (during the first quarter of 2005); this represents an event rate of approximately $1 \%$ per annum. By this time the trial will have $80 \%$ power to detect an observed 22\% reduction in CHD events (based on the intention-to-treat method of analysis). This will also provide $90 \%$ power to detect a $25 \%$ relative reduction in CHD events (based on intention-to-treat analysis). These calculations assumed an average drop-out rate from active treatment of $10 \%$ over the course of the study but allowed for a larger drop-in rate from placebo to open-cholesterol treatment of $17 \%$ * by the mid-point of the trial and $32 \%$ by study close, in view of the possible increased uptake of statin therapy after the Heart Protection Study. ${ }^{7}$ ( $T h$ is was incorrectly referred to as $10 \%$ in the FIELD design paper, ${ }^{1}$ the assumption used in the original power calculations.)

Therefore, follow-up in the study, as stipulated in the protocol, was to be for a median duration of not less than 5 years and until 500 major coronary events had occurred, unless the study was terminated prematurely on the recommendation of the independent Safety and Data Monitoring Committee.

\section{Results}

Of the 13900 patients screened in study clinics, $75.9 \%$ (10 553) proceeded to enter the placebo run-in phase and $73.4 \%$ (10 203) the active run-in phase, and ultimately 9795 (70.5\%) patients were randomized (Figure 1). The demographic characteristics are shown for the randomized and nonrandomized patients in Table 1. The study cohort included more men than women, and had a mean age in the mid-60s, and just over 2100 randomized patients had a prior history of cardiovascular disease.

There were 6051 subjects randomized from Australia, 2351 from New Zealand and 1393 from Finland. There were no differences across the 3 countries in mean ages of patients or ages at diagnosis (55.8 years, 53.0 years and 56.2 years for Australia, Finland and New Zealand, respectively). The median periods from diabetes diagnosis to randomization were 5, 7 and 5 years, respectively. The patients recruited were a mix from hospital and the community, and therefore were diverse in absolute risk. The 7664 participants who had no history of cardiovascular disease were at lower risk on the basis of interim determination using the modified Framingham equation of the UKPDS Risk Engine (Table 2) [20,21]. The prevalence rates of the various components of the metabolic syndrome (using criteria from NCEP ATP III definitions) at baseline are detailed in Table 3. A total of $84 \%$ of subjects met the ATP III criteria for metabolic syndrome. Baseline biochemistry for the entire randomized cohort and the effects of the 6 weeks of treatment with comicronized fenofibrate are shown in Table 4. On average, there was a $10 \%$ reduction in total cholesterol, a $10 \%$ reduction in LDL cholesterol, a $26 \%$ reduction in triglycerides and a $6.5 \%$ increase in HDL cholesterol after this short-term exposure to the active agent (average HDL increase was $6.1 \%$ in men versus $7.3 \%$ in women). Apolipoprotein B levels fell by an average of $14 \%$, and the total-to-HDL cholesterol ratio by about $15 \%$. Creatinine levels increased by an average of nearly 13\% (an effect that is believed to be reversible and harmless, though not fully understood) $[22,23]$, and fibrinogen levels fell by $11 \%$. 


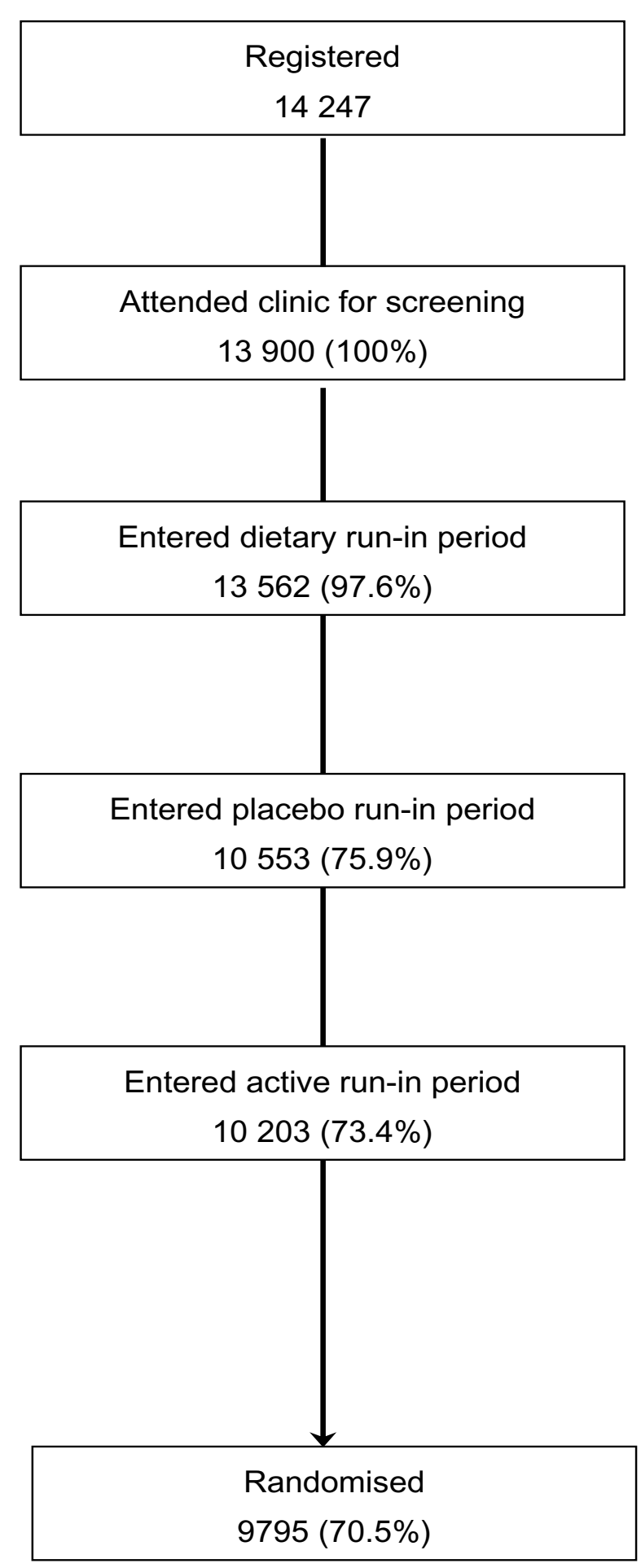

Figure I

Numbers of patients enrolled in the run-in phases of the trial.

\section{Discussion}

Almost all lipid-modifying trials that have included patients with diabetes have used statins as the intervention agent. Data on the effects of statin therapy among more than 18000 persons with type 2 diabetes are now available and show important reductions in coronary and vascular events [24]. Those studies involving more than 1000 people with diabetes include Anglo-Scandinavian Cardiac Outcomes Trial (ASCOT) [5], the Long-Term Intervention with Pravastatin in Ischaemic Disease (LIPID) study, [5] the Antihypertensive and Lipid-Lowering Treatment to Prevent Heart Attack Trial (ALLHAT-LLT) [4], the Heart Protection Study [7] and the most recently reported trial, the Collaborative Atorvastatin Diabetes Study (CARDS). CARDS used atorvastatin, $10 \mathrm{mg} /$ day, and showed a $36 \%$ reduction in combined cardiovascular endpoints $(2.46 \%$ per year for placebo and $1.54 \%$ for atorvastatin-treated) [8]. The results from a similarly structured trial (Atorvastatin Study for Prevention of Coronary Heart Disease Endpoints in Non Insulin Dependent Diabetes Mellitus, ASPEN) are pending.

Two large-scale trials of fibrate therapy have also been completed: the Veterans Low-HDL Cholesterol Intervention Trial (VA-HIT) and the Bezafibrate Infarct Prevention (BIP) trial enrolled subjects with and without diabetes mellitus. Both studies were limited to people with prior myocardial infarction and reported reductions in major cardiovascular events among participants with low HDL and high triglycerides at baseline, which were greater than with use of the same fibrate among those without dyslipidemia $[11,25]$. The VA-HIT trial also reported lower coronary heart disease mortality in those with diabetes receiving gemfibrozil and reduced cardiovascular events, though rates of nonfatal myocardial infarction did not change significantly [11]. A third, smaller, trial that used a fibrate, the Diabetes Atherosclerosis Intervention Study (DAIS), showed reduced progression of established coronary atherosclerosis among those randomized to fenofibrate compared with those receiving matching placebo over 3 years [10].

The identification of the PPAR transcription factor as the primary pathway through which fibrate and glitazoneagonist actions are triggered [18] has stimulated renewed interest in the antiatherogenic effects of these agents. PPAR-alpha activation by fibrates has the potential to prevent atherosclerosis via regulation of lipid metabolism and hemostatic pathways $[26,27]$. Consequently, there is great interest in the FIELD study because it will generate clinical information about fibrates in diabetes similar to that which is already available for the statins.

These baseline data of the FIELD study cohort without known prior cardiovascular disease show that over half 
Table I: Baseline characteristics of the FIELD study cohort

\begin{tabular}{|c|c|c|c|c|c|}
\hline \multirow[t]{2}{*}{ Characteristic } & \multirow[t]{2}{*}{ Category } & \multicolumn{2}{|c|}{$\begin{array}{c}\text { Screened, not } \\
\text { randomized } \\
(n=4 \mid 05)\end{array}$} & \multicolumn{2}{|c|}{$\begin{array}{c}\text { Randomized } \\
(n=9795)\end{array}$} \\
\hline & & $n$ & $\%$ & $n$ & $\%$ \\
\hline \multirow[t]{2}{*}{ Sex } & Male & 2424 & 59.0 & 6138 & 62.7 \\
\hline & Female & $168 \mid$ & 41.0 & 3657 & 37.3 \\
\hline \multirow[t]{5}{*}{ Age at Visit I (years) } & $<55$ & 682 & 16.6 & 1668 & 17.0 \\
\hline & $55-59$ & 802 & 19.5 & 1976 & 20.2 \\
\hline & $60-64$ & 856 & 20.8 & 2196 & 22.4 \\
\hline & $65-69$ & 888 & 21.7 & 2202 & 22.5 \\
\hline & $70+$ & 877 & 21.4 & 1753 & 17.9 \\
\hline \multirow[t]{4}{*}{ Ethnicity* } & Caucasian & 3757 & 91.5 & 9093 & 92.8 \\
\hline & Indigenous & 161 & 3.9 & 258 & 2.6 \\
\hline & Asian & 93 & 2.3 & $|4|$ & 1.4 \\
\hline & Other & 94 & 2.3 & 303 & 3.1 \\
\hline \multirow[t]{4}{*}{ Body mass index $\left(\mathrm{kg} / \mathrm{m}^{2}\right)(\mathrm{BMI})$} & BMI $<25$ & 805 & 19.6 & 1198 & 12.2 \\
\hline & $25 \leq \mathrm{BMI}<30$ & $151 \mid$ & 36.8 & 3855 & 39.4 \\
\hline & $30 \leq \mathrm{BMI}<35$ & 1099 & 26.8 & 2869 & 29.3 \\
\hline & $\mathrm{BMI} \geq 35$ & 652 & 15.9 & 1866 & 19.1 \\
\hline \multirow[t]{2}{*}{ Waist (cm) } & Female $($ mean $\pm \mathrm{SD})$ & $98 \pm 15$ & & $101 \pm 14$ & \\
\hline & Male $($ mean $\pm S D)$ & $103 \pm 13$ & & $105 \pm 12$ & \\
\hline \multirow[t]{5}{*}{ Waist-hip ratio } & ratio $<0.8$ & 242 & 5.9 & 333 & 3.4 \\
\hline & $0.8 \leq$ ratio $<0.9$ & 1184 & 28.8 & 2531 & 25.8 \\
\hline & $0.9 \leq$ ratio $<1.0$ & 1931 & 47.0 & 4942 & 50.5 \\
\hline & $1.0 \leq$ ratio $<1.1$ & 645 & 15.7 & 1797 & 18.4 \\
\hline & ratio $\geq$ I.I & 73 & 1.8 & 179 & 1.8 \\
\hline \multirow[t]{3}{*}{ Smoking (cigarettes) } & Nonsmoker & 1735 & 42.3 & 4000 & 40.8 \\
\hline & Ex-smoker & 1933 & 47.1 & 4908 & 50.1 \\
\hline & Current smoker & 404 & 9.8 & 887 & 9.1 \\
\hline \multirow[t]{7}{*}{ Clinical history } & Prior cardiovascular disease $\dagger$ & 1045 & 25.4 & 2131 & 21.8 \\
\hline & Prior myocardial infarction & 278 & 6.7 & 485 & 5.0 \\
\hline & Stroke & 194 & 4.7 & 346 & 3.5 \\
\hline & Angina & 588 & 14.3 & 1188 & 12.1 \\
\hline & Hypertension & 2247 & 54.7 & 5544 & 56.6 \\
\hline & Claudication or peripheral vascular disease & 351 & 8.6 & 711 & 7.2 \\
\hline & Transient ischemic attack & 155 & 3.8 & 307 & 3.1 \\
\hline \multirow[t]{4}{*}{ Prior coronary revascularisation } & No CABG or PTCA & 3908 & 95.2 & 9432 & 96.3 \\
\hline & CABG only & 122 & 3.0 & 230 & 2.4 \\
\hline & PTCA only & 49 & 1.2 & 102 & 1.0 \\
\hline & CABG and PTCA & 26 & 0.6 & 31 & 0.3 \\
\hline \multirow[t]{4}{*}{ Diabetes management } & Diet only & 1119 & 27.3 & 2542 & 26.0 \\
\hline & Diet $+\mathrm{OH}$ only & 2238 & 54.5 & 5874 & 60.0 \\
\hline & Diet + insulin & 429 & 10.5 & 569 & 5.8 \\
\hline & Diet $+\mathrm{OH}+$ insulin & 319 & 7.8 & 810 & 8.3 \\
\hline \multirow[t]{5}{*}{ Diabetic complications $\ddagger$} & Retinopathy & 431 & 10.5 & 814 & 8.3 \\
\hline & Neuropathy & 636 & 15.5 & 1394 & 14.2 \\
\hline & Nephropathy & 161 & 3.9 & 279 & 2.9 \\
\hline & Skin ulcers & 139 & 3.4 & 299 & 3.1 \\
\hline & Amputations & 106 & 2.6 & 176 & 1.8 \\
\hline \multirow[t]{2}{*}{ Diabetes diagnosis $\ddagger$} & Age at diagnosis (mean $\pm S D$ ) & $54.8 \pm 8.7$ & & $55.5 \pm 8.3$ & \\
\hline & Median duration of diabetes in years (quartile I, quartile 3) & $6(2,11)$ & & 52,10 & \\
\hline
\end{tabular}

* Patients are assumed to be Caucasian unless otherwise stated. Indigenous includes Aborigines, Torres Strait Islanders, Maori and Pacific Islanders. Other includes mixed races, African-American, Indian, African, etc.

† Prior cardiovascular disease is defined as a reported history of myocardial infarction, angina (stable and unstable), coronary revascularization (CABG or PTCA), stroke, claudication or peripheral vascular disease or peripheral revascularization before randomization. The count includes 13 randomized patients and 10 nonrandomized patients who suffered or reported a cardiovascular event during the run-in period (visit I to visit 4 (randomization)).

$\ddagger$ Diabetic complications and age at diabetes diagnosis are self-reported.

$\mathrm{CABG}=$ coronary artery bypass grafting; $\mathrm{PTCA}=$ percutaneous transluminal coronary angioplasty; $\mathrm{SD}=$ standard deviation; $\mathrm{OH}=\mathrm{oral}$

hypoglycemic agents 
Table 2: Distribution of projected 5-year risk (\%, UKPDS risk engine) of coronary and other vascular outcomes for randomized patients with no history of cardiovascular disease $(n=7664)$

\begin{tabular}{|c|c|c|c|c|c|}
\hline \multirow{2}{*}{$\begin{array}{l}\text { Outcome } \\
\text { measures }\end{array}$} & \multicolumn{5}{|c|}{ Projected 5-year risk (\%, from the UKPDS risk engine) } \\
\hline & $<5 \%$ & $5 \%-<10 \%$ & $10 \%-<15 \%$ & $15 \%-<20 \%$ & $\geq \mathbf{2 0} \%$ \\
\hline All CHD & 24.6 & 37.0 & 20.7 & 9.5 & 8.2 \\
\hline Fatal CHD & 56.1 & 26.8 & 9.9 & 4.6 & 2.6 \\
\hline All stroke & 79.3 & 17.0 & 2.8 & 0.7 & 0.2 \\
\hline Fatal stroke & 99.9 & 0.1 & 0.0 & 0.0 & 0.0 \\
\hline
\end{tabular}

Table 3: Prevalence of various components of the metabolic syndrome among the 9795 randomized participants in the FIELD study

\begin{tabular}{|c|c|c|c|c|c|c|}
\hline \multirow[b]{2}{*}{ Metabolic syndrome feature: ATPIII criteria * } & \multicolumn{2}{|c|}{$\begin{array}{c}\text { Men } \\
(n=6 \mid 38)\end{array}$} & \multicolumn{2}{|c|}{$\begin{array}{l}\text { Women } \\
(n=3657)\end{array}$} & \multicolumn{2}{|c|}{$\begin{array}{c}\text { Total } \\
(n=9795)\end{array}$} \\
\hline & $n$ & $\%$ & $n$ & $\%$ & $n$ & $\%$ \\
\hline Waist measurement (women $>88 \mathrm{~cm}$; men $>102 \mathrm{~cm}$ ) & 3613 & 58.9 & 3034 & 83.0 & 6647 & 67.9 \\
\hline Triglycerides $>=1.7 \mathrm{mmol} / \mathrm{L}$ & 3073 & 50.1 & 2020 & 55.2 & 5093 & 52.0 \\
\hline $\mathrm{HDL}($ men $<40 \mathrm{mg} / \mathrm{dL}$; women $<50 \mathrm{mg} / \mathrm{dL}$ ) & 3365 & 54.8 & 2455 & 67.1 & 5820 & 59.4 \\
\hline Hypertension (SBP >= 130 and DBP $>=85 \mathrm{~mm} \mathrm{Hg}$ ) & 5050 & 82.3 & 3131 & 85.6 & 8181 & 83.5 \\
\hline Fasting glucose $>=110 \mathrm{mg} / \mathrm{dL}$ or diabetes & 6133 & 99.9 & 3646 & 99.7 & 9779 & 99.8 \\
\hline
\end{tabular}

* When 3 of the 5 listed characteristics are present, a diagnosis of metabolic syndrome is established ( $84 \%$ of the cohort met the criteria)

Table 4: Baseline fasting biochemistry for the 9795 randomized participants in the FIELD study

\begin{tabular}{|c|c|c|c|c|c|c|}
\hline \multirow[b]{2}{*}{ Parameter } & \multicolumn{4}{|c|}{ Baseline } & \multicolumn{2}{|c|}{$\begin{array}{l}\text { After } 6 \text { weeks of } \\
\text { fenofibrate }\end{array}$} \\
\hline & Mean & SD & Median & Q1, Q3 & Mean & SD \\
\hline Total cholesterol (mmol/L) & $5.04 *$ & 0.69 & $5.03 *$ & $4.56,5.54$ & 4.49 & 0.69 \\
\hline HDL cholesterol (mmol/L)ף & $1.10 *$ & 0.26 & $1.06 *$ & $0.92,1.24$ & 1.16 & 0.29 \\
\hline Calculated LDL cholesterol (mmol/L) & $3.07 *$ & 0.64 & $3.08 *$ & $2.62,3.51$ & 2.71 & 0.62 \\
\hline Triglycerides (mmol/L) & $1.94 *$ & 0.88 & $1.74^{*}$ & $1.34,2.34$ & 1.37 & 0.63 \\
\hline Total-to-HDL cholesterol ratio & $4.81 *$ & 1.10 & $4.7 I^{*}$ & $4.04,5.49$ & 4.08 & 1.13 \\
\hline Apolipoprotein B $(g / L)$ & $0.97 *$ & 0.17 & $0.97 *$ & $0.86,1.09$ & 0.83 & 0.18 \\
\hline Creatinine $(\mathrm{mmol} / \mathrm{L})$ & $0.08 \dagger$ & 0.02 & $0.08 \dagger$ & $0.07,0.09$ & 0.09 & 0.02 \\
\hline Fibrinogen $(g / L)$ & $3.6+$ & 0.8 & $3.6 \dagger$ & $3.1,4.1$ & 3.12 & 0.75 \\
\hline Fasting glucose $(\mathrm{mmol} / \mathrm{L})$ & $8.9 \dagger$ & 2.6 & $8.5 \dagger$ & $7.0,10.3$ & -- & -- \\
\hline Urinary albumin-to-creatinine ratio $(\mathrm{mg} / \mathrm{mmol})$ & $5.9+$ & 21.8 & $1.2 \dagger$ & $0.7,3.0$ & -- & -- \\
\hline Homocysteine $(\mu \mathrm{mol} / \mathrm{L})$ & $10.2 \S$ & 3.7 & $9.5 \S$ & $7.9,11.6$ & -- & -- \\
\hline Insulin (mU/L) & $15.7 \ddagger$ & 24.0 & $12.0 \ddagger$ & $8.0,18.5$ & -- & -- \\
\hline $\mathrm{HbAlc}(\%)$ & $7.1+$ & 1.4 & $6.9+$ & $6.1,7.8$ & -- & -- \\
\hline
\end{tabular}

* Average of Visit 2 and Visit 3.

$\dagger$ Average of Visit I and Visit 3.

$\ddagger$ Visit I only.

$\S$ Visit 3 only.

TI Baseline HDLc (mean $\pm \mathrm{SD}$ ): men $=1.03 \pm 0.23 \mathrm{mmol} / \mathrm{L}$, women $=1.21 \pm 0.28 \mathrm{mmol} / \mathrm{L}$

|| All changes at six weeks were statistically significant at $P<0.000$ I

-- not measured 
such patients had a (UKPDS-determined) calculated 5year coronary heart disease risk of less than $10 \%$ and nearly all patients had a stroke risk of less than $10 \%$ over 5 years. Part of the reason for this low-risk status may be that the duration of diabetes was only 5 years, on average, and reflecting this short duration, the median HbA1c was $6.9 \%$ for the entire cohort and the proportion of patients using no diabetes glucoregulatory therapy was just over a quarter. This probably reflects the recruitment process, in that many community-based subjects chose to enter the study in response to information provided by newsletters sent through Diabetes Australia, the Finnish Diabetes Society, the New Zealand Society for the Study of Diabetes and a New Zealand national diabetes consumer database.

Nonetheless, the cohort still had a profile with many characteristics of high cardiovascular risk. Half of the patients were obese (BMI > 30), most were male, two-thirds were over the age of 60 years, and substantial proportions had NCEP ATP III features of the metabolic syndrome additional to their diabetes mellitus, including low HDL cholesterol, either high blood pressure measurement and/or treatment for hypertension, high waist measurement and raised triglyceride. Over $2100(22 \%)$ had established cardiovascular disease, and 39\% of those without known cardiovascular disease had a projected 5-year absolute risk of a coronary event higher than $10 \%$.

Evaluation of the effect of comicronized fenofibrate over 6 weeks immediately before randomization was included in the protocol. The purpose of this was to measure the effect of the agent in the entire cohort. After 6 weeks there were major reductions in triglycerides, lesser decreases in LDL cholesterol, and rises in HDL cholesterol. Creatinine levels rose while fibrinogen fell, several of the effects that have been observed elsewhere and with other fibrate agents $[28,29]$.

Approximately 140 million adults were estimated to have diabetes mellitus in 1997; it is the most common endocrine disorder worldwide. Projections put diabetes prevalence by 2010 at 221 million, about 60 percent higher. Just as many people again have an elevated fasting glucose level, or impaired fasting glucose, which can progress rapidly to diabetes [30]. Without the FIELD study data, doctors would remain uncertain about the merits of using PPAR-alpha agonists, with or without concomitant statin therapy, when confronted with a patient with diabetes mellitus. The study will have special application to showing the effect of PPAR alpha agonist action on cardiovascular outcomes in those with low HDL dyslipidemic profiles. The main results of the FIELD study will be reported in late 2005.

\section{Declaration of competing interests}

Of the Management Committee of the FIELD Study:

PB, YAK and RS have received reimbursements, fees, funding, or salary in the past five years from an organization that may in any way gain or lose financially from the publication of this paper;

No authors hold or have held stocks or shares in such an organization;

No authors have other financial competing interests;

AK has the following nonfinancial competing interest: Advisory board membership.

\section{Authors' contributions}

The Writing Committee are the authors responsible for this article.

\section{Study organization Writing committee}

R Scott, J Best, P Forder, M-R Taskinen, J Simes, P Barter, A Keech

\section{Management Committee}

P Barter*, J Best*, P Colman, M d'Emden, T Davis, P Drury, C Ehnholm, P Glasziou, D Hunt, A Keech* (study chairman and principal investigator), YA Kesaniemi, M Laakso, R Scott* , RJ Simes*, D Sullivan, M-R Taskinen*, M Whiting; J-C Ansquer, B Fraitag (non-voting sponsor representatives). ${ }^{*}$ Executive Committee members

\section{Outcomes Assessment Committee}

N Anderson, G Hankey, D Hunt (chairman), S Lehto, S Mann, M Romo; LP Li (outcomes officer, in attendance),

\section{Safety and Data Monitoring Committee}

C Hennekens, S MacMahon (chairman), S Pocock, A Tonkin, L Wilhelmsen; P Forder (unblinded statistician, in attendance).

\section{Site Principal investigators}

Australia: H Akauola, F Alford, P Barter, I Beinart, J Best, S Bohra, S Boyages, P Colman, H Connor, D Darnell, T Davis, P Davoren, F Lepre, F De Looze, M d'Emden, A Duffield, R Fassett, J Flack, G Fulcher, S Grant, S Hamwood, D Harmelin, R Jackson, W Jeffries, M Kamp, L Kritharides, L Mahar, V McCann, D McIntyre, R Moses, H Newnham, G Nicholson, R O'Brien, K Park, N Petrovsky, P Phillips, G Pinn, D Simmons, K Stanton, B Stuckey, D R Sullivan, M Suranyi, M Suthers, Y Tan, M Templer, D Topliss, J H Waites, G Watts, T Welborn, R Wyndham; Finland: H Haapamaki, A Kesaniemi, M Laakso, J Lahtela, H Levanen, J Saltevo, H Sodervik, M Taskinen, M Vanhala; 
New Zealand: J Baker, A Burton, P Dixon, J Doran, P Drury, P Dunn, N Graham, A Hamer, J Hedley, J Lloyd, P Manning, I McPherson, S Morris, C Renner, R Scott, R Smith, M Wackrow, S Young.

\section{Co-investigators and site coordinators}

Australia: F Alard, J Alcoe, F Alford, C Allan, J Amerena, R Anderson, N Arnold, T Arsov, D Ashby, C Atkinson, L Badhni, M Balme, D Barton, B Batrouney, C Beare, T Beattie, J Beggs, C Bendall, C Bendall, A Benz, A Bond, R Bradfield, J Bradshaw, S Brearley, D Bruce, J Burgess, J Butler, M Callary, J Campbell, K Chambers, J Chow, S Chow, K Ciszek, P Clifton, P Clifton-Bligh, V Clowes, P Coates, C Cocks, S Cole, D Colquhoun, M Correcha, B Costa, S Coverdale, M Croft, J Crowe, S Dal Sasso, W Davis, J Dunn, S Edwards, R Elder, S El-Kaissi, L Emery, M England, O Farouque, M Fernandez, B Fitzpatrick, N Francis, P Freeman, A Fuller, D Gale, V Gaylard, C Gillzan, C Glatthaar, J Goddard, V Grange, T Greenaway, J Griffin, A Grogan, S Guha, J Gustafson, P S Hamblin, T Hannay, C Hardie, A Harper, G Hartl, A Harvey, S Havlin, K Haworth, P Hay, L Hay, B Heenan, R Hesketh, A Heyworth, M Hines, G Hockings, A Hodge, L Hoffman, L Hoskin, M Howells, D Hunt, A Hunt, W Inder, W Inder, D Jackson, A Jovanovska, K Kearins, P Kee, J Keen, D Kilpatrick, J Kindellan, M Kingston-Ray, M Kotowicz, A Lassig, M Layton, S Lean, E Lim, F Long, L Lucas, D Ludeman, D Ludeman, C Ludeman-Robertson, M Lyall, L Lynch, C Maddison, B Malkus, A Marangou, F Margrie, K Matthiesson, J Matthiesson, S Maxwell, K McCarthy, A McElduff, H McKee, J McKenzie, K McLachan, P McNair, M Meischke, A Merkel, C Miller, B Morrison, A Morton, W Mossman, A Mowat, J Muecke, P Murie, S Murray, P Nadorp, S Nair, J Nairn, A Nankervis, K Narayan, N Nattrass, J Ngui, S Nicholls, V Nicholls, JA Nye, E Nye, D O'Neal, M O'Neill, S O'Rourke, J Pearse, C Pearson, J Phillips, L Pittis, D Playford, L Porter, L Porter, R Portley, M Powell, C Preston, S Pringle, W A Quinn, J Raffaele, G Ramnath, J Ramsden, D Richtsteiger, S Roffe, S Rosen, G Ross, Z Ross, J Rowe, D Rumble, S Ryan, J Sansom, C Seymour, E Shanahan, S Shelly, J Shepherd, G Sherman, R Siddall, D Silva, S Simmons, R Simpson, A Sinha, R Slobodniuk, M Smith, P Smith, S Smith, V Smith-Orr, J Snow, L Socha, T Stack, K Steed, K Steele, J Stephensen, P Stevens, G Stewart, R Stewart, C Strakosch, M Sullivan, S Sunder, J Sunderland, E Tapp, J Taylor, D Thorn, D Thorn, A Tolley, D Torpy, G Truran, F Turner, J Turner, J van de Velde, S Varley, J Wallace, J Walsh, J Walsh, J Walshe, G Ward, B Watson, J Watson, A Webb, F Werner, E White, A Whitehouse, N Whitehouse, S Wigg, J Wilkinson, E Wilmshurst, D Wilson, G Wittert, B Wong, M Wong, S Worboys, S Wright, S Wu, J Yarker, M Yeo, K Young, J Youssef, R Yuen, H Zeimer, R W Ziffer; Finland: A Aura, A Friman, J Hanninen, J Henell, N Hyvarinen, M Ikonen, A Itkonen, J Jappinen, A Jarva, T Jerkkola, V Jokinen, J Juutilainen, H Kahkonen, T Kangas, M Karttunen,
P Kauranen, S Kortelainen, H Koukkunen, L Kumpulainen, T Laitinen, M Laitinen, S Lehto, R Lehto, E Leinonen, M Lindstron-Karjalainen, A Lumiaho, J Makela, K Makinen, L Mannermaa, T Mard, J Miettinen, V Naatti, S Paavola, N Parssinen, J Ripatti, S Ruotsalainen, A Salo, M Siiskonen, A Soppela, J Starck, I Suonranta, L Ukkola, K Valli, J Virolainen; New Zealand: P Allan, W Arnold, W Bagg, K Balfour, T Ball, B Ballantine, C Ballantyne, C Barker, C Barker, F Bartley, E Berry, G Braatvedt, A Campbell, T Clarke, R Clarke, A Claydon, S Clayton, P Cresswell, R Cutfield, J Daffurn, J Delahunt, A Dissnayake, C Eagleton, C Ferguson, C Florkowski, D Fry, P Giles, M Gluyas, C Grant, P Guile, M Guolo, P Hale, M Hammond, M Hammond, P Healy, M Hills, J Hinge, J Holland, B Hyne, A Ireland, A Johnstone, S Jones, G Kerr, K Kerr, M Khant, J Krebs, L Law, B Lydon, K MacAuley, R McEwan, P McGregor, B McLaren, L McLeod, J Medforth, R Miskimmin, J Moffat, M Pickup, C Prentice, M Rahman, E Reda, C Ross, A Ryalls, D Schmid, N Shergill, A Snaddon, H Snell, L Stevens, A Waterman, V Watts.

\section{Coordinating centre teams}

NHMRC Clinical Trials Centre, Sydney: K Jayne, E Keirnan, P Newman, G Ritchie, A Rosenfeld (project directors), E Beller, P Forder, V Gebski, A Pillai (study statisticians), C Anderson, S Blakesmith, S-Y Chan, S Czyniewski, A Dobbie, S Doshi, A Dupuy, S Eckermann, $\mathrm{M}$ Edwards, N Fields, K Flood, S Ford, C French, S Gillies, C Greig, M Groshens, J Gu, Y Guo, W Hague, S Healy, L Hones, Z Hossain, M Howlett, J Lee, L-P Li, T Matthews, J Micallef, A Martin, I Minns, A Nguyen, F Papuni, A Patel, J Pearse, R Pike, M Pena, K Pinto, D Schipp, J Schroeder, B Sim, C Sodhi, T Sourjina, C Sutton, R Taylor, P Vlagsma, S Walder, R Walker, W Wong, J Zhang, B Zhong, A Keech (deputy director), RJ Simes (director); Helsinki Project Office: A Kokkonen, P Narva, E-L Niemi, A Salo, A-M Syrjanen, M-R Taskinen (director); Christchurch Project Office: C Lintott, R Scott (director).

\section{Central laboratories}

Adelaide: R Tirimacco, M Whiting; Helsinki: C Ehnholm, M Ikonen, M Kajosaari, L Raman, J Sundvall, M Tukianen.

Laboratoires Fournier SA liaison: Dijon: J-C Ansquer, B Fraitag, D Crimet, I Sirugue, Sydney: P Aubonnet.

\section{Acknowledgements}

The FIELD study is supported by a grant from Laboratoires Fournier SA, Dijon, France and is being coordinated independently by the National Health and Medical Research Council Clinical Trials Centre, University of Sydney, Sydney, Australia, and overseen by the study Management Committee.

The study is also supported by the National Health and Medical Research Council, Australia (Unit grant, Project grant, and Fellowships to A. Keech and J. Simes), without which it would not be possible. We thank the 
National Heart Foundation, Australia, Diabetes Australia, Diabetes New Zealand, and the Finnish Diabetes Association for endorsing the study. Investigators express their thanks to Rhana Pike for her assistance with the preparation of this manuscript. Finally, the many patients participating in the FIELD study are thanked for their untiring contributions.

\section{References}

I. FIELD Study Investigators: The need for a large-scale trial of fibrate therapy in diabetes: the rationale and design of the Fenofibrate Intervention and Event Lowering in Diabetes (FIELD) study. ISRCTN6478348 I. Cardiovasc Diabetol 2004, 3:9.

2. Scandinavian Simvastatin Survival Study Group: Randomised trial of cholesterol lowering in $\mathbf{4 4 4 4}$ patients with coronary heart disease; the Scandinavian Simvastatin Survival Study (4S). Lancet 1994, 344: I383-1389.

3. Goldberg RB, Mellies MJ, Sacks FM, Moye LA, Howard BV, Howard WJ, Davis BR, Cole TG, Pfeffer MA, Braunwald E: Cardiovascular events and their reduction with pravastatin in diabetic and glucose-intolerant myocardial infarction survivors with average cholesterol levels: subgroup analyses in the cholesterol and recurrent events (CARE) trial. The Care Investigators. Circulation 1998, 98:2513-2519.

4. ALLHAT Officers and Coordinators for the ALLHAT Collaborative Research Group: The Antihypertensive and Lipid-Lowering Treatment to Prevent Heart Attack Trial: Major outcomes in moderately hypercholesterolemic, hypertensive patients randomized to pravastatin vs usual care: The Antihypertensive and Lipid-Lowering Treatment to Prevent Heart Attack Trial (ALLHAT-LLT). JAMA 2002, 288:2998-3007.

5. Sever PS, Dahlöf B, Poulter NR, Wedel H, Beevers G, Caulfield M, Collins R, Kjeldsen SE, Kristinsson A, Mclnnes GT, Mehlsen J, Nieminen M, O'Brien E, Ostergren J, ASCOT investigators, et al.: Prevention of coronary and stroke events with atorvastatin in hypertensive patients who have average or lower-than-average cholesterol concentrations, in the Anglo-Scandinavian Cardiac Outcomes Trial-Lipid Lowering Arm (ASCOTLLA): a multicentre randomised controlled trial. Lancet 2003, 36I: I149-1158.

6. Keech AC, Colquhoun D, Best J, Kirby A, Simes RJ, Hunt D, Hague W, Beller E, Arulchelvam M, Baker J, Tonkin A, for the LIPID study group, et al.: Secondary prevention of cardiovascular events with long-term pravastatin in patients with diabetes or impaired fasting glucose: results from the LIPID trial. Diabetes Care 2003, 26:27|3-2721.

7. Heart Protection Study Collaborative Group: MRC/BHF Heart Protection Study of cholesterol lowering with simvastatin in 5963 people with diabetes: a randomised placebo-controlled trial. Lancet 2003, 36 I:2005-2016.

8. Colhoun HM, Betteridge DJ, Durington PN, Hitman GA, Neil HA, Livingstone SJ, Thomason MJ, Mackness MI, Charlton-Menys V, Fuller JH, on behalf of the CARDS Investigators: Primary prevention of cardiovascular disease with atorvastatin in type 2 diabetes in the Collaborative Atorvastatin Diabetes Study (CARDS); multicentre randomised placebo controlled trial. Lancet 2004, 364:685-696.

9. The BIP Study Group: Secondary prevention by raising HDL cholesterol and reducing triglycerides in patients with coronary artery disease. The Bezafibrate Infarction Prevention (BIP) Study. Circulation 2000, 102:21-27.

10. Diabetes Atherosclerosis Intervention Study Investigators: Effect of fenofibrate on progression of coronary artery disease in type 2 diabetes: the Diabetes Atherosclerosis Intervention Study, a randomised study. Lancet 200I, 357:905-9I0.

II. Rubins HB, Robins SJ, Collins D, Nelson DB, Elam MB, Schaefer EJ, Faas FH, Anderson JW, for the VA-HIT Study Group: Diabetes, plasma insulin and cardiovascular disease. Subgroup analysis from the Department of Veterans Affairs high-density lipoprotein intervention trial (VA-HIT). Arch Intern Med 2002, 162:2597-2604.

12. Elkeles RS, Diamond JR, Poulter C, Dhanjil S, Nicolaides A, Mahmood $S$, Richmond W, Mather H, Sharp P, Feher MD: Cardiovascular outcomes in type 2 diabetes: A double-blind placebo-controlled study of bezafibrate: The St. Mary's, Ealing, Northwick Park Diabetes Cardiovascular Disease Prevention (SENDCAP) Study. Diabetes Care 1998, 21:64I-642.
13. Meade T, Zuhrie R, Cook C, Cooper J, on behalf of MRC: General Practice Research Framework: Bezafibrate in men with lower extremity arterial disease: randomized controlled trial. BMJ 2002, 325: I-5.

14. Koskinen P, Mänttäri M, Manninen V, Huttunen JK, Heinonen OP, Frick MH: Coronary heart disease incidence in NIDDM patients in the Helsinki Heart Study. Diabetes Care 1992, 15:820-825.

15. Laakso M, Voutilainen E, Sarlund H, Aro A, Pyorala K, Penttila I: Serum lipids and lipoproteins in middle aged non-insulin dependent diabetics. Atherosclerosis 1985, 56:271-28I.

16. Feingold KR, Grunfeld C, Pang M, Doerrler W, Krauss RM: LDL subclass phenotypes and triglyceride metabolism in non-insulin dependent diabetes. Arterioscler Thromb 1992, I 2:1496-1 502.

17. Staels B, Dallongeville J, Auwerx J, Schoonjans K, Leitersdorf E, Fruchart JC: Mechanisms of action of fibrates on lipid and lipoprotein metabolism. Circulation 1998, 98:2088-2093.

18. Schoonjans K, Staels B, Auwerx J: Role of the peroxisome proliferator-activated receptor (PPAR) in mediating the effects of fibrates and fatty acids on gene expression. J Lipid Res 1996, 37:907-925

19. Friedewald WT, Levy RI, Fredrickson DS: Estimation of the concentration of low-density lipoprotein cholesterol in plasma, without use of the preparative ultracentrifuge. Clin Chem 1972, 18:499-502.

20. Stevens RJ, Kothari V, Adler Al, Stratton IM, Holman RR: The UKPDS risk engine: a model for the risk of coronary heart disease in type II diabetes (UKPDS 56). Clin Sci 200I, 101:67|-679.

2I. Kothari V, Stevens RJ, Adler Al, Stratton IM, Manley SE, Neil HA, Holman RR: UKPDS 60: risk of stroke in type 2 diabetes estimated by the UK Prospective Diabetes Study risk engine. Stroke 2002, 33:|776-178|

22. Westphal S, Dierkes J, Luley C: Effects of fenofibrate and gemfibrozil on plasma homocysteine. Lancet 200I, 358:39-40.

23. Ansquer J-C, Foucher C, Rattier S, Taskinen M-R, Steiner G, for the DAIS Investigators: Fenofibrate reduces progression to microalbuminuria over three years in a placebo-controlled study in type 2 diabetes : results from the Diabetes Atherosclerosis Intervention Study (DAIS). Am J Kidney Dis 2005, 44:485-493.

24. Cholesterol Treatment Trialists' Collaborators: Efficacy and safety of cholesterol-lowering treatment: prospective meta-analysis of data from 90056 participants in 14 randomised trials of statins. Lancet 2005, 366: I 267-1278.

25. Tenenbaum A, Motro M, Fisman EZ, Tanne D, Boyko V, Behar S: Bezafibrate for the secondary prevention of myocardial infarction in patients with metabolic syndrome. Arch Int Med 2005, 165: II54-1260.

26. Rizos E, Mikhailidis DP: Are high-density lipoprotein and triglyceride levels important in secondary prevention: impressions from the BIP and VA-HIT trials. Int J Cardiol 2002, 82:199-207.

27. Keating GM, Ormrod D: Micronised fenofibrate. An updated review of its clinical efficacy in the management of dyslipidaemia. Drugs 2002, 62:1909-1944.

28. Elisaf M: Effects of fibrates on serum metabolic parameters. Curr Med Res Opin 2002, 18:269-276.

29. Genest J, Frohlich J, Steiner G: Effect of fenofibrate-mediated increase in plasma homocysteine on the progression on coronary artery disease in type $\mathbf{2}$ diabetes mellitus. Am J Cardiol 2004, 93:848-853.

30. Cameron AJ, Shaw JE, Zimmet PZ: The metabolic syndrome: prevalence in worldwide populations. Endocrinol Metab Clin North Am 2004, 33:35I-375. 